\title{
Trypanosoma evansi AND Neospora caninum AMONG WATER BUFFALOES (Bubalus bubalis) IN THE PHILIPPINES
}

\author{
Claro N. Mingala ${ }^{1,2}$, Jaypee A. Abenoja ${ }^{2}$, Christopher V. Rivera ${ }^{2}$, Michelle M. Balbin ${ }^{1}$, Virginia M. \\ Venturina $^{2}$, Marvin A. Villanueva ${ }^{1}$ \\ ${ }^{1}$ Biosafety and Environment Section, Philippine Carabao Center National Headquarters and Gene \\ Pool, ${ }^{2}$ College of Veterinary Science and Medicine, Central Luzon State University
}

Corresponding author: cnmingala@hotmail.com

\begin{abstract}
The study determined the positivity rate of Trypanosoma evansi and Neospora caninum antibodies in water buffaloes in the province of Nueva Ecija, Philippines using Polymerase Chain Reaction (PCR) for $T$. evansi and competitive Enzyme-linked Immunosorbent Assay (cELISA) for N. caninum antibodies. A total of 100 whole blood and 100 serum samples were collected to test for $T$. evansi and $N$. caninum, respectively. Rotat 1.2 VSG gene was target using PCR for T. evansi detection. Neospora caninum antibody detection was done from the serum samples using cELISA test kit. Results revealed that the positivity rate of $T$. evansi in Nueva Ecija was $11 \%(11 / 100)$. The positive animals identified were from the municipalities of Muñoz (4/16; 25\%), Sta. Rosa (3/13; 23.08\%) and Talugtug (4/16; $25 \%)$. The seropositive rate of Nueva Ecija for $N$. caninum. was $46 \%$ (46/100), seropositive animals were identified in Cabanatuan City, $57.14 \%$ (4/7); Science City of Muñoz, 43.14\% (22/51); Sta. Rosa, 40\% (4/10); Sto. Domingo, 50\% (6/12); and Talugtug $50 \%(10 / 20)$. The seropositivity rate of $N$. caninum and the presence of $T$. evansi in Nueva Ecija may contribute to the cases of abortions in the province and further studies should be employed to confirm the association of these organisms to abortion cases on water buffaloes.
\end{abstract}

Keywords: Trypanosoma; Neospora; PCR; cELISA; water buffalo. 


\section{INTRODUCTION}

Philippine water buffalo (Bubalus bubalis) is one of the most important livestock in many developing countries due to its adaptability to hot and humid tropical areas (Villanueva et al., 2016). It has a significant role in the agricultural economy of many developing countries such as providing meat and milk for nutrition and draught power for agriculture and transport (De Alwis et al., 1999). In the Philippines, the population of water buffalo is about 2.88 million heads (PSA, 2016), majority of the contributors are smallholder farmers who prefer water buffalo as a livestock animal over cattle for its ability to perform optimally under relatively adverse environmental conditions (De Alwis et al., 1999) and considered more resistant to several bovine tropical diseases (Warriach et al., 2015). Despite these merits, water buffaloes are not excused from infectious agents that cause abortion leading to a compromised reproductive efficiency.

Abortion is the delivery of an immature fetus, either dead or alive before the expected parturition time as a result of failure of the mechanisms that control pregnancy (Shaapan, 2016). Both noninfectious (nutritional, physical, toxic and chemical) and infectious (viral, bacterial, fungal and protozoal) etiologies can result in pregnancy loss. Infectious agents are perhaps the most frequently thought of cause of abortions in human and domestic animals (Pretzer, 2008) and these includes some abortigenic protozoans. The most common protozoal diseases responsible for abortion incidence in domestic animals are neosporosis (Dubey and Lindsay, 1996), trypanosomiasis (Lun et al., 1993), sarcocystosis (Shaapan, 2016), toxoplasmosis (Pretzer, 2008) and trichomoniasis (Sanjrani et al., 2013). However, at present, there is limited epidemiological information and data regarding abortion in water buffaloes in Nueva Ecija leading to insufficient consideration given to the implementation of systematic control measures against major abortifacient infectious agents in livestock (Konnai et al., 2008). Few studies have been carried out on the identification of agents causing abortion in livestock animals, however, such studies focus mainly on cattle (Bombio et al., 2010, Konnai et al., 2008, Ochirkhuu et. al., 2015) and limited on water buffaloes.

The study on these protozoal agents of water buffaloes will give knowledge on the positivity rate of $T$. evansi and $N$. caninum antibodies in Nueva Ecija. This will give information about the possible presence of these parasites and can be used by future studies to confirm the agent itself especially $N$. caninum and to provide a better understanding on the economic impacts of these pathogens and a basis for control and preventive measures on the area.

\section{MATERIALS AND METHODS}

\section{Sample collection}

A total of 200 blood samples of apparently healthy water buffaloes were collected randomly in selected municipalities and cities in northern Philippines. These buffaloes were restrained in a chute and approximately $5 \mathrm{ml}$ of blood samples were collected aseptically via jugular venipuncture or at the coccygeal vein. One hundred blood samples were collected in tubes with anticoagulant for $T$. evansi detection while the rest of the samples were placed in tubes without anticoagulant to easily separate the serum. Collected samples were transported immediately to the laboratory for processing. 
DNA extraction and PCR for the detection of $T$. evansi

Whole blood samples with EDTA were extracted using the conventional DNA extraction method.

PCR reaction mixture was prepared in a master mix with a total volume of $12.5 \mu \mathrm{L}$ containing: $2 \mu \mathrm{T} \mathrm{Taq}$ Buffer, $0.2 \mu \mathrm{l}$ dNTP mixture, $0.8 \mu \mathrm{l}$ $\mathrm{MgCl}_{2}, 0.05 \mu \mathrm{l}$ Taq Polymerase, $0.25 \mu \mathrm{l}$ of each primer, $1.5 \mu \mathrm{l}$ of extracted DNA and $7.45 \mu \mathrm{l}$ of DDW.

Specific primers used for the detection of $T$. evansi amplify an approximately 205 base pairs (bp) gene fragment of the RoTat 1.2 VSG gene (AF317914), The primer pair is as follows:

5'GCGGGGTGTTTAAAGCAATA-3' and 5'-ATTAGTGCTGCGTGTGTTCG-3'.

This primer pair targets the DNA region lacking homology to other known VSG genes. According to Claes et al. (2004) PCR amplification of the RoTat 1.2 VSG gene is a specific marker for $T$. evansi strains, except for $T$. evansi type $B$, but it was believed that this $T$. evansi type B strain is not present in the study area and it was only observed in a specific place in Isiolo district in Kenya (Ngaira et al., 2004).

PCR was performed under the following cycling conditions: an initial denaturation at $93^{\circ} \mathrm{C}$ for $3 \mathrm{~min}$, followed by 30 cycles of $93^{\circ} \mathrm{C}$ for $30 \mathrm{sec}$ (denaturation), $45^{\circ} \mathrm{C}$ for $30 \mathrm{sec}$ (annealing), $72^{\circ} \mathrm{C}$ for $1 \mathrm{~min}$. (extension) and $72^{\circ} \mathrm{C}$ for $5 \mathrm{~min}$ (final extension) (Chaudhry et al., 2009).

PCR products were visualized by Agarose Gel Electrophoresis. A mixture of GelRed stain and $3 \mu \mathrm{L}$ each of the PCR product were loaded in $2 \%$ agarose gel along with 100 bp DNA marker and was run at $100 \mathrm{~V}$ for 30 minutes. The amplified products were visualized as a single compact band of expected size ( 205) under UV light and documented by a gel documentation system installed in the FluorChem $\mathrm{E}$ machine (ProteinSimple, Santa Clara, CA, United States).

cELISA test for the detection of $N$. caninum antibodies

$N$. caninum antibody in water buffalo sera were detected using a specific kit, competitive enzyme-linked immunosorbent assay (cELISA) (VMRD Inc., Pullman, WA, USA). Preparation of samples and test procedure were conducted following the manufacturer's instructions indicated on the test kit protocol.

This cELISA detects antibody to $N$. caninum in bovine sera. Sample serum antibody to $N$. caninum inhibits binding of horseradish peroxidase (HRP)labeled $N$. caninum specific monoclonal antibody to $N$. caninum antigen coated on the plastic wells. Binding of the HRPlabeled monoclonal antibody conjugate is detected by the addition of enzyme substrate and quantified by subsequent color product development. Strong color development indicates little or no blockage of HRP-labeled monoclonal antibody binding and therefore the absence of $N$. caninum antibody in sample sera. Weak color development due to inhibition of the monoclonal antibody binding to the antigen on the solid phase indicates the presence of $N$. caninum antibodies in sample sera.

\section{RESULTS AND DISCUSSION}

Molecular detection of T. evansi using PCR

A total of 100 extracted DNA samples from water buffalo blood were tested for the presence of $T$. evansi using PCR and showed an overall positivity rate of $11 \%(11 / 100)$ in Nueva Ecija. Table 1 shows that, 4 out of 16 $(25 \%)$ in Science City of Muñoz, 3 out of $13(23.08 \%)$ in Sta. Rosa and 4 out of $16(25 \%)$ in Talugtug tested positive while samples from Cabanatuan City, Carranglan, Lupao, San Jose City and 
San Leonardo tested negative for $T$. evansi infection.

Table 1. PCR results for $T$. evansi detection

\begin{tabular}{lccc}
\hline Collection Site & $\begin{array}{c}\text { Total Number of } \\
\text { Animals Tested }\end{array}$ & $\begin{array}{l}\text { No. of Positive } \\
\text { Animals }\end{array}$ & Percentage (\%) \\
\hline Cabanatuan City & 7 & 0 & 0 \\
Carranglan & 5 & 0 & 0 \\
Lupao & 10 & 0 & 0 \\
Science City of Muñoz & 16 & 4 & 25 \\
San Jose City & 16 & 0 & 0 \\
San Leonardo & 17 & 0 & 0 \\
Sta. Rosa & 13 & 3 & 23.08 \\
Talugtug & 16 & 4 & 25 \\
\hline \multicolumn{1}{c}{ TOTAL } & $\mathbf{1 0 0}$ & $\mathbf{1 1}$ & $\mathbf{1 1}$ \\
\hline
\end{tabular}

Figure 1 shows the gel electrophoresis result indicating positive cases of $T$. evansi in the tested DNA samples. Positive samples were revealed as bands lined in approximately $205 \mathrm{bp}$.
The PCR assay confirmed the parasite as $T$. evansi, the agent of Surra, as the amplicons displayed the specific 205 bp band under UV transilluminator after gel electrophoresis.

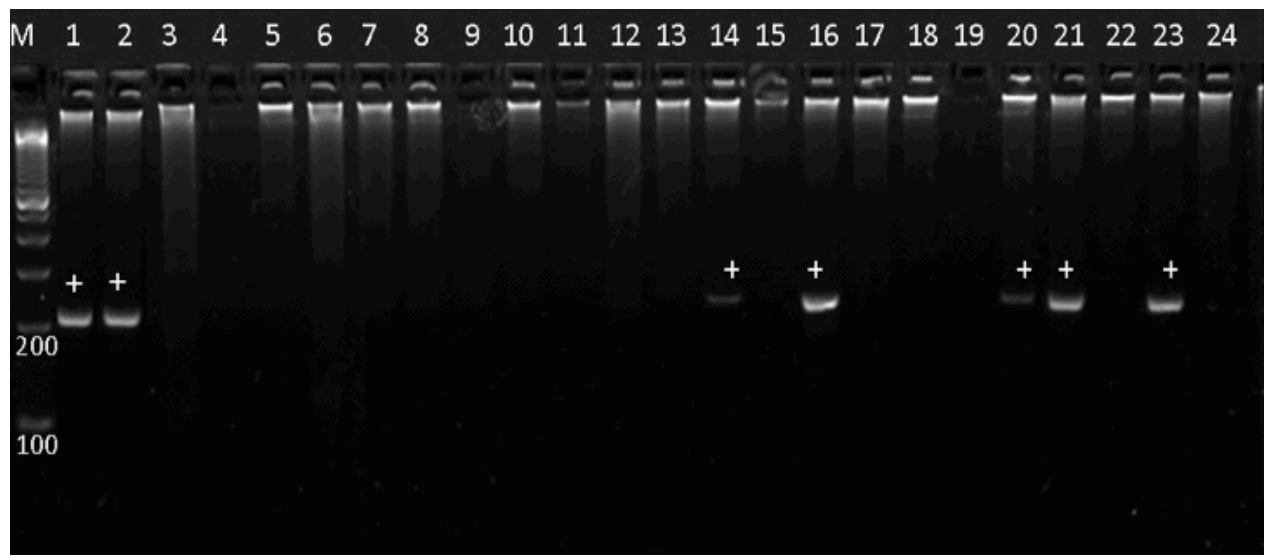

Figure 1. Agarose gel visualization of the PCR amplification ( 205bp) for the detection of $T$. evansi Rotat 1.2 VSG gene. Marker -100bp DNA ladder; lane 1 is the positive control while lanes $2,14,16,20,21$ and 23 are positive samples at $\sim 205$ target bp.

Eight (8) water buffaloes in Talugtug and Science City of Muñoz were found to be positive with $T$. evansi using PCR. These two areas are geographically close to each other which may imply that the organism may have a higher chance of being transmitted into other water buffaloes within the area or the surrounding municipalities in the region. This imposes potential economic losses to the farmers because of decreased draught output, milk production and reproduction losses of infected buffaloes as effect of having the organism (Dargantes et al., 2009). In the Philippines, tabanid fly or horsefly is the primary transmitter of $T$. evansi (Baticados et al., 2011a) but other blood-sucking insects like stable fly (Stomoxys calcitrans), buffalo fly (Haematobia spp. and mosquito (Manuel, 1998) are also believed to transmit the parasite mechanically. Tabanids are widely distributed in the 
country and its population greatly increases during rainy season (OIE, 2009), coincidentally same season where the blood samples were collected for this study.

The result of this study supports some prevalence studies regarding Surra cases in Nueva Ecija. The present findings of this study showed remarkably higher positivity rate in Science City of Muñoz (25\%), Sta. Rosa (23.08), and Talugtug (25\%) compared to the prevalence study of Parayao (Unpublished) in Talavera (14.53\%), and Miguel (Unpublished) in Rizal (16.84\%). Meanwhile, Lagasca (Unpublished) reported a high prevalence of trypanosomosis in San Jose City (25.93 $\%)$ in which the current study detected none in the same city.

Moreover, in this study, the overall positivity rate of $T$. evansi infection in Nueva Ecija is $11 \%$ which is higher compared to the study of Baticados et al. (2011b) who reported a prevalence of $7.14 \%(3 / 42)$ of Surra among cattle in Saguday, Quirino using PCR and Medrano (Unpublished) who reported $7.33 \%$ and $10.19 \%$ T. evansi infection prevalence among cattle and swamp buffaloes, respectively, in Aurora province using microscopy. Konnai et al. (2008) conducted a survey of abortifacient infectious agents in livestock in Luzon, Philippines. From the study, among the 105 buffalo samples collected, $1.9 \% \quad(2 / 105)$ was tested positive with $T$. evansi. Likewise, based on the study conducted by Baticados et al. (2011a) on parasitological and PCR detection of $T$. evansi in water buffaloes from Luzon, Philippines, two of the 145 samples $(0.13 \%)$ were positive for $T$. evansi in both, blood parasite examination and PCR.

The economic importance of $T$. evansi infection in the ruminant industry is most obvious when the disease already causes mortality, but even the sub-clinical infections have been shown to cause high losses from reduced feed efficiency and weight gain low milk production, and poor reproductive performance (Wint et al., 2008).

\section{Detection of antibodies to $N$. caninum using cELISA}

Results showed that 46 out of 100 serum samples (46\%) from different cities and municipalities of Nueva Ecija were tested seropositive. Table 2 shows that, 4 out of $7(57.14 \%)$ water buffaloes in Cabanatuan City, 22 out of 51 $(43.14 \%)$ water buffaloes in Science City of Muñoz, 4 out of 10 (40\%) water buffaloes in Sta. Rosa, 6 out of $12(50 \%)$ water buffaloes in Sto. Domingo and 10 out of $20(50 \%)$ water buffaloes in Talugtug recorded to have antibody titers against $N$. caninum.

Table 2. cELISA results for the detection of antibodies to $N$. caninum in serum sample of water buffaloes collected from 2017 to 2018.

\begin{tabular}{lccc}
\hline \multicolumn{1}{c}{ Collection site } & $\begin{array}{c}\text { Total number of animals } \\
\text { tested }\end{array}$ & No. of positive & Percentage (\%) \\
\hline Cabanatuan & 7 & 4 & 57.14 \\
Science City of & 51 & 22 & 43.14 \\
Muñoz & & & \\
Sta. Rosa & 10 & 4 & 40 \\
Sto. Domingo & 12 & 6 & 50 \\
Talugtug & 20 & 10 & 50 \\
\hline \multicolumn{1}{c}{ TOTAL } & $\mathbf{1 0 0}$ & $\mathbf{4 6}$ & $\mathbf{4 6}$ \\
\hline
\end{tabular}

Serum antibody from the sample inhibits the binding of enzyme-labeled monoclonal antibody to $N$. caninum antigen coated on the plastic wells. 
Figure 2 shows the computed percentage inhibition of antibodies, threshold of $30 \%$ inhibition (broken line) serum samples that reached the

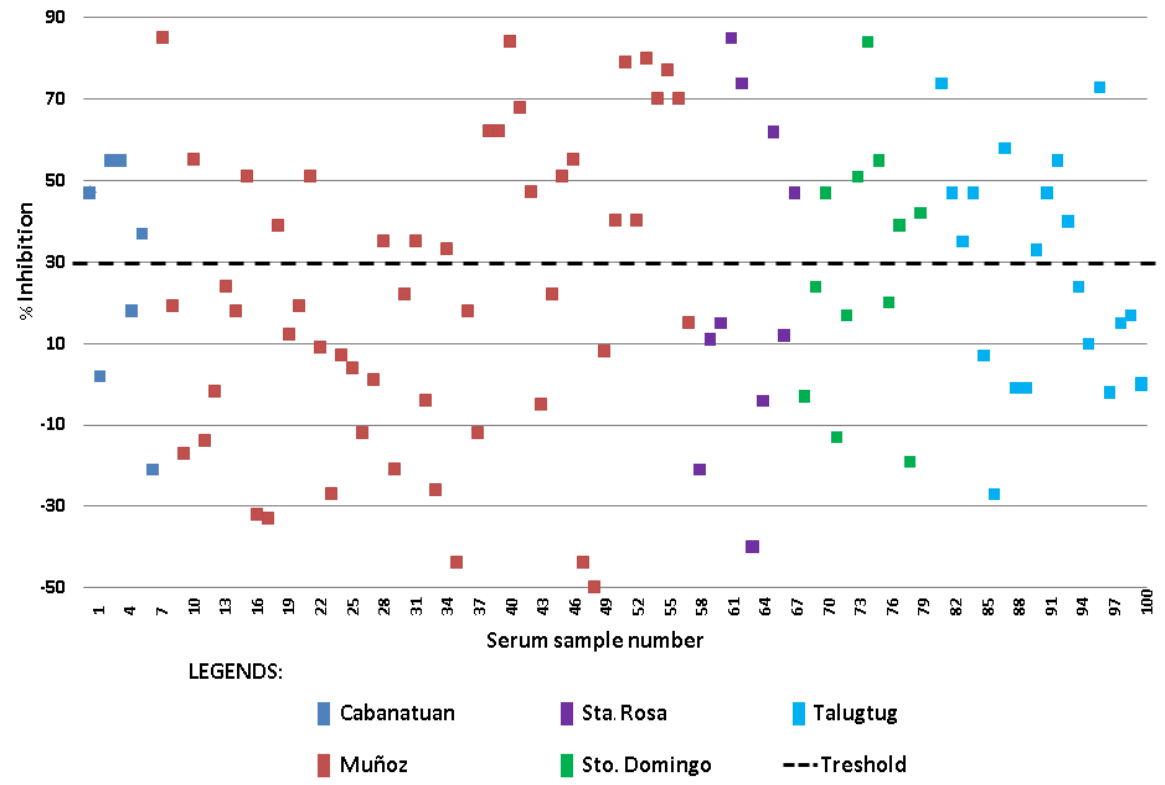

Figure 2. Percent inhibition values of $N$. caninum antibodies detected by cELISA in Water buffaloes from Nueva Ecija, Philippines collected from 2017-2018.

$N$. caninum is considered to be one of the major causes of abortion in cattle (Dubey et al., 1996) and implicated also in abortion cases in water buffalo (Guarino et al., 2000). In this study, a high proportion of seropositive animals from all the municipalities detected seropositive for $N$. caninum (Table 2), this is higher compared to the individual level seroprevalence study conducted by Abes and Divina (2008) in Nueva Ecija (27.3\%) which included the municipalities of Aliaga, Cabanatuan City, Carranglan, Cuyapo, General Tinio, Guimba, Llanera, Science City of Muñoz, Quezon, Rizal, San Jose, Sto. Domingo, Talavera and Talugtug. Presence of $N$. caninum antibodies has been already investigated in other countries and included as a differential diagnosis for abortion cases among water buffaloes (da Silva, et al., 2017). This study showed that the total seropositivity rate of $N$. caninum antibodies in Nueva Ecija is $46 \%$; this was higher compared to the prevalence reported by Sadrebazzaz et al. (2004) in Mashhad, Iran with a prevalence of $15.18 \%$. Nam et al. (2012) reported that $4.5 \%$ of swamp buffaloes tested was positive in northeastern Thailand. Sevgili and Gul Altas (2005) found antibodies to $N$. caninum in 23 of the $305(7.5 \%)$ cow sera based on ELISA test results in the province of Sanliurfa, Turkey. According to the serological surveys, the prevalence of $N$. caninum infection in water buffaloes were reported to be at $64 \%$ in Southeastern region of Brazil (Fujii et al., 2001), 1.5\% in South of Vietnam (Huong et al., 1998), 68\% in Egypt (Dubey et al., 1998), 34.6\% in Southern Italy (Guarino et al., 2000) and $37 \%$ in Iran (Hajikolaei et al., 2007).

The difference in results between this study and others conducted on the river buffaloes could be due to the different tests used, age groups, geography, season, management and/or breeds. Importation of water buffaloes was also a factor for the possibility that these animals might have been infected 
before they arrived in the country and then served as a source of infection to the definitive and intermediate hosts of N. caninum (Abes and Divina, 2008). Domestic and stray dogs, definitive hosts, on farms have an easy access to placentas and the ingestion of infected placentas and fetal tissues can lead to the shedding of $N$. caninum oocysts (McAllister et al., 1998; Dijkstra et al., 2001).

Other studies on the detection of antibodies to $N$. caninum through ELISA requires or uses confirmatory tests to provide a stronger evidence of exposure to infection for the reason that, the animals who are seropositive to ELISA does not necessarily mean that they were infected but it may indicate the occurrence of the organism (Abes and Divina, 2008). In a study conducted by Meenakshi et al. (2007) in India, they detected the presence of $N$. caninum antibodies using cELISA among water buffaloes with a prevalence of $52.3 \%$ in adults and $45.4 \%$ in heifers and later used Indirect Fluorescent Antibody Test (IFAT) to verify the ELISA results.

In this study, although confirmatory tests like IFAT were not conducted, the high seropositivity of animals to ELISA supports the assumption that this protozoal agent might be present in the province. Its economic importance in water buffalo industry, and detection of this parasite to dogs cohabitating with water buffaloes should also be investigated. Dogs are generally known as the definitive host of this parasite. They shed parasite oocysts in their feces which can be ingested by grazing water buffaloes through contaminated grass. The other way around, uninfected dogs can horizontally acquire $N$. caninum through ingestion of aborted materials like fetuses and placenta infected with the parasite. Farmers should be well aware of these modes of spread to create measures that prevent disease occurrence.

\section{CONCLUSION}

In conclusion, the current study was able to provide a molecular and serological evidence of the presence of $T$. evansi and $N$. caninum antibodies, respectively, among water buffaloes in Nueva Ecija. However, further studies should be employed to determine whether the presence of $T$. evansi and antibodies to $N$. caninum in the province are associated to abortion. It is recommended that the quality of DNAextracted samples for PCR should be checked targeting $\beta$-actin as housekeeping gene. DNA-extracted samples should also be identified using a more sensitive technique like DNA sequencing for confirmation of the parasite. Similar studies should consider expanding the number of samples to be collected and larger collection area.

Future studies should consider risk factor analysis, such as mode of transmission of this disease, potential vectors and intermediate hosts in the area, entry of new stock in the area through importation, animal movement and dispersal project practices, knowledge of the farmer to the disease, and grazing distance of one animal to another.

\section{ACKNOWLEDGMENTS}

We thank the PCC for the support to finish the study. Likewise, to the Philippine Council for Agriculture, Aquatic, and Natural Resources Research and Development (PCAARRD) for funding and monitoring this project. Special thanks to all the staff of the Biosafety and Environment Section of PCC for their technical assistance. 


\section{INFORMATION NOTES}

The experiment was approved by the Committee of Ethics on Animal Use of the sector of Agrarian Sciences of the Federal University of Paraná, Curitiba, PR, Brazil, under protocol n. 027/2017.

\section{REFERENCES}

ABES, N. S.; DIVINA, B. P. Seroprevalence of Neospora caninum in Bulgarian Murrah buffaloes and its detection in domestic dogs from buffalo dairy herds in Nueva Ecija, Philippines. Philippine Journal of Veterinary Medicine, v.45, p.30-38, 2008.

BARLING, K. S.; MCNEILL, J. W.; THOMPSON, J. A.; et al. Association of serologic status for Neospora caninum with post weaning weight gain and carcass measurements in beef calves. Journal of American Veterinary Medical Association, v.217, p.13561360, 2000.

BATICADOS, W. N.; CASTRO, D. L.; BATICADOS, A. M. Parasitological and PCR detection of Trypanosoma evansi in buffaloes from Luzon, Philippines. Ceylon Journal of Science (Biological Science), v.40, n.2, p.141-146, $2011 a$.

BATICADOS, W. N.; FERNANDEZ, C. P.; BATICADOS, A. M. Molecular detection of Trypanosoma evansi in cattle from Quirino Province, Philippines. Veterinarski Arhiv, v.81, p.635-646, 2011b.

BOMBIO, A. M.; DIVINA, B. P. Seroprevalence of Neospora caninum antibodies in selected dairy cattle herds from Laguna and Quezon Provinces, Philippines. Philippine Journal of Veterinary Medicine, v.46, n.2, p.82-86, 2010.

CHAUDHRY, Z. I.; JAHANZAIB, A.; ASLAM, A.; et al. Prevalence of Trypanosoma evansi in camels through polymerase chain reaction and haematocrit centrifugation techique in
Punjab (Pakistan). Journal of Camel

Practice and Research, v.15, n.2, p.183-185, 2009.

CLAES, F.; RADWANSKA, M.; URAKAWA, T.; et al. Variable surface glycoprotein RoTat 1.2 PCR as a specific diagnostic tool for the detection of Trypanosoma evansi infections. Kinetoplastid Biology and Disease, v.3, p.3, 2004.

DARGANTES, A. P.; MERCADO, R. T.; DOBSON, R. J.; et al. Estimating the impact of Trypanosoma evansi infection (Surra) on buffalo population dynamics in southern Philippines using data from cross-sectional surveys. International Journal of Parasitology, v.39, p.11091114, 2009.

DA SILVA, J. B.; NICOLINO, R. R.; FAGUNDES, G. M.; et al. Serological survey of Neospora caninum and Toxoplasma gondii in cattle (Bos indicus) and water buffaloes (Bubalus bubalis) in ten provinces of Brazil. Comparative Microbiology and Infectious Diseases, v.52, pp.30-35, 2017.

DE ALWIS, M. C. L.; SUBASINGHE, D. H. A.; HORADAGODA, N. U. Water buffalo in Asia IV: Diseases of the Buffalo. National Science Foundation 47/5, Maitland Place, Colombo 7, Sri Lanka, 1999.

DIJKSTRA, T.; EYSKER, M.; SCHARES, G.; et al. Dogs shed Neospora caninum oocysts after ingestion of naturally infected bovine placenta but not after ingestion of colostrum spiked with Neospora caninum tachyzoites. International Journal of Parasitology, v.31, n.8, p.747-752, 2001.

DUBEY, J. P.; ROMAND, S.; HILALI, M.; et al. Seroprevalence of antibodies to Neospora caninum and Toxoplasma gondii in water buffaloes (Bubalus bubalis) from Egypt. International 
Journal of Parasitology, v.28, n.3, p.527-529, 1998.

DUBEY, J. P.; LINDSAY, D. S. A review of Neospora caninum and neosporosis. Veterinary Parasitology, v.67, p.1-59, 1996.

FUJII, T. U.; KASAI, N.; NISHI, S. M.; et al. Seroprevalence of Neospora caninum in female water buffaloes (Bubalus bubalis) from the southeastern region of Brazil. Veterinary Parasitology, v.99, n.4, p.331-334, 2001.

GUARINO, A.; FUSCO, G.; SAVINI, G.; et al. Neosporosis in water buffaloes (Bubalus bubalis) in southern Italy. Veterinary Parasitology, v.91, p.15-21, 2000

HAJIKOLAEI, M.; SAAD, G.; HOSSAIN, $\mathrm{H}$.; et al. Occurrence of Neospora caninum antibodies in water buffaloes (Bubalus bubalis) from the southwestern region of Iran. Bulletin of the Veterinary Institute in Pulawy, v.51, p.233-235, 2007.

HUONG, L. T. T.; LJUNGSTORM, B. L.; UGGLA, A.; BJORKMAN, C. Prevalence of antibodies to Neospora caninum and Toxoplasma gondii in cattle and water buffaloes in southern Vietnam. Veterinary Parasitology, v.75, p.53-57, 1998.

KONNAI, S.; MINGALA, C. N.; SATO, M.; et al. A survey of abortifacient infectious agents in livestock in Luzon, the Philippines, with emphasis on the situation in a cattle herd with abortion problems. Acta Tropica, v.105, n.3, p.269-273, 2008.

LUN, Z. R.; FANG, Y.; WANG, C. J.; BRUN, R. Trypanosomiasis of domestic animals in China. Parasitology Today, v.9, p.41-45, 1993

MANUEL, M. F. Sporadic outbreaks of Surra in the Philippines and its economic impact. Journal of Protozoology Research, v.8, p.131-138, 1998.
MCALLISTER, M. M.; DUBEY, J. P.; LINDSAY, D. S.; et al. Dogs are definitive hosts of Neospora caninum. International Journal of Parasitology, v.28, p.1473-1478, 1998.

MEENAKSHI, K.; SANDHU, S.; BALL, M. S.; et al. Seroprevalence of Neospora caninum antibodies in cattle and water buffaloes in India. Journal of Parasitology, v.93, n.6, p.1374-1377, 2007.

NAM, N. H.; CHANLUN, A.; KANISTANON, K.; et al. Seroprevalence of Neospora caninum in swamp buffaloes and beef cattle in the northeast of Thailand. Thai Journal of Veterinary Medicine, v.42, n.2, p.213-218, 2012.

NGAIRA, J. M.; NJAGI, E. N. M.; NGERANWA, J. J. N.; et al. PCR amplification of RoTat 1.2 VSG gene in Trypanosoma evansi isolates in Kenya. Veterinary Parasitology, v.120, p.2333, 2004.

OCHIRKHUU, N.; KONNAI, S.; MINGALA, C. N.; et al. Molecular epidemiological survey and genetic analysis of vector-borne infections of cattle in Luzon Island, the Philippines. Veterinary Parasitology, v.212, n.3-4 p.161-167, 2015.

OIE. Trypanosoma evansi infections (including Surra). OIE Terrestrial Manual, World Organization for Animal Health, 2009. Available from http://www.oie.int/fileadmin/home/eng/an imal_health_in_the_world/docs/pdf/trypa no_evansi_final.pdf. Access on 28 June 2018 .

PRETZER, S. Bacterial and protozoal causes of pregnancy loss in the bitch and queen. Theriogenology, v.70, n.3, p.320-326, 2008.

PSA. Carabao Industry Performance Report, Philippine Statistics Authority, 2016. Available from https://psa.gov.ph/content/carabao- 
industry-performance-report-22016.

Access on 28 July 2018.

SADREBAZZAZ, A.; HADDADZADEH, H.; ESMAILNIA, K.; et al. Serological prevalence of Neospora caninum in healthy and aborted dairy cattle in Mashhad, Iran. Veterinary Parasitology, v.124, p.201-204, 2004.

SANJRANI, S. N.; MIRBAHAR, K. B.; SOOMRO, $\mathrm{H}$.; et al. Prevalence of abortion in Kundhi buffalo in district Hyderabad, Sindh, Pakistan. Herald Journal of Agriculture and Food Science Research, v.2, n.1, p.70-77, 2013.

SEVGILI, M.; GUL ALTAS, $M$. Seroprevalence of Neospora caninum in cattle in the province of Sanliurfa. Turkish Journal of Veterinary and Animal Science, v.29, p.127-130, 2005.

SHAAPAN, R. M. The common zoonotic protozoal diseases causing abortion. Journal of Parasitic Diseases, v.40, n.4, p.1116-1129, 2016.

SOULSBY, E. J. W. Helminths, Arthropods, and Protozoa of Domesticated Animals. $7^{\text {th }}$ ed. Bailliere Tindall: Lea and Febriger, London, 1982.

VILLANUEVA, M. A.; MINGALA, C. N.; GLORIANI, N. G.; et al. Serological investigation of Leptospira infection and its circulation in one intensive-type water buffalo farm in the Philippines. Japanese Journal of Veterinary Research, v.64, n.1, p.15-24, 2016.

WARRIACH, H. M.; MCGILL, D. M.; BUSH, R. D.; et al. A review of recent developments in buffalo reproduction. Asian-Australasian Journal of Animal Science, v.28, n.3, p.451-455, 2015.

WINT, W.; BOURN, D.; MOLINA, J. Q.; et al. Animal disease distribution modelling and risk mapping in the Philippines: Liver Fluke (Fasciolosis) and Surra (Trypanosomosis). EAHMI Policy Brief 1. Food and Agriculture Organisation of the United Nations and Philippine Department of Agriculture's

$\begin{array}{lcr}\begin{array}{l}\text { Environmental } \\ \text { Management }\end{array} & \begin{array}{l}\text { Animal } \\ \text { Initiative. }\end{array} & \begin{array}{r}\text { Health } \\ \text { doi: }\end{array} \\ \text { 10.13140/RG.2.1.1600.2963, 2008. } & \end{array}$

